\title{
Rooting depth and below ground biomass in a freshwater coastal marsh invaded by European Reed (Phragmites australis) compared with remnant uninvaded sites at Long Point, Ontario
}

\author{
Calvin Lei ${ }^{1}$, Sarah J. Yuckin ${ }^{1}$, and Rebecca C. Rooney ${ }^{1}$, * \\ ${ }^{1}$ Department of Biology, University of Waterloo, 200 University Avenue West, Waterloo, Ontario N2L 3G1 Canada \\ *Corresponding author: rrooney@uwaterloo.ca
}

Lei, C., S.J. Yukin, and R.C. Rooney. 2019. Rooting depth and below ground biomass in a freshwater coastal marsh invaded by European Reed (Phragmites australis) compared with remnant uninvaded sites at Long Point, Ontario. Canadian Field-Naturalist 133(4): 364-371. https://doi.org/10.22621/cfn.v133i4.2281

\begin{abstract}
Invasive European Reed (Phragmites australis subsp. australis) outcompetes native vegetation, reducing floristic diversity and habitat value for wildlife. Research in coastal salt marshes has indicated that $P$. australis invasion may be facilitated by its relatively deep rooting depth, but in freshwater marshes the growth pattern of below ground tissues in relation to water depth is uncertain. To determine if $P$. australis is rooting more deeply than resident wetland plant species in a freshwater coastal marsh on Lake Erie, Ontario, we measured the vertical distribution of below ground biomass in $P$. australis invaded marsh sites and compared it to the below ground biomass distribution in nearby sites not yet invaded by $P$. australis. These invaded and uninvaded sites were paired by water depth, which is known to influence resource allocation and rooting depth. Below ground biomass in invaded sites was greater than in uninvaded sites $\left(t_{28}=3.528, P=0.001\right)$, but rooting depth (i.e., the depth at which $90 \%$ of total below ground biomass is accounted for) was comparable $\left(t_{28}=0.992, P=0.330\right)$. Using water depth and site type, general linear models could predict below ground biomass $\left(F_{2,55}=9.115, P<0.001\right)$ but not rooting depth $\left(F_{2,55}=1.175, P=0.316\right)$. Rooting depth is likely affected by other factors such as substrate type and the depth of the organic soil horizon.
\end{abstract}

Key words: Below ground biomass; coastal marsh; Common Reed; ecosystem effects; invasive species; Lake Erie; rhizomes; roots; wetland

\section{Introduction}

European Reed (Phragmites australis (Cavanilles) Trinius ex Steudel subsp. australis) is considered highly invasive in North America (Saltonstall 2002) and has profound negative effects on both coastal and inland wetlands and shores. Researchers have reported that $P$. australis replaces native vegetation (Able et al. 2003; Tulbure and Johnston 2010), lowers plant biodiversity (Keller 2000), and disrupts wetland integrity and ecological function (Windham and Ehrenfeld 2003; Rothman and Bouchard 2007; Tulbure and Johnston 2010; Duke et al. 2015). Phragmites australis invasion may also lead to sediment accretion, terrain flattening, and a reduction in water-filled depressions due to the accumulation of leaf litter and rhizome biomass (Able et al. 2003). These invasion-driven changes in wetland habitat have consequences such as the loss of toad breeding habitat (Greenberg and Green 2013), reduced abundance of at-risk birds (Robichaud and Rooney 2017), and fewer suitable nesting areas and poor microhab- itats for turtle eggs (Bolton and Brooks 2010; Cook 2016). Consequently, P. australis was named the worst invasive plant species in Canada (Catling and Mitrow 2005, 2011).

In the Great Lakes region, P. australis has replaced thousands of hectares of freshwater coastal wetlands. Around Lake Erie alone, invasion estimates range from 2553 ha within the coastal wetlands (Carson et al. 2018) to 8233 ha within a $10 \mathrm{~km}$ buffer around the American portion of Lake Erie (Bourgeau-Chavez et al. 2013). At Long Point on Lake Erie, P. australis invasion is predicted to continue expanding rapidly until 2022 (Jung et al. 2017), and the wetland communities most commonly replaced are cattail, meadow marsh, sedge and grass hummocks, and other mixed emergent communities (Wilcox et al. 2003).

The invasion success of $P$. australis is due to advantageous morphological features and its ability to modify its environment. For example, $P$. australis stems can grow up to five metres tall, intercepting light and shading competitors (Hirtreiter and Potts 
2012). With its large seed heads, P. australis can produce hundreds of wind-dispersed seeds (Tulbure and Johnston 2010), which is an important strategy for creating new individuals (Albert et al. 2015). However, local expansion mainly occurs by vegetative growth (Albert et al. 2015), using stolon fragments and rhizomes (Mal and Narine 2004; Tulbure and Johnston 2010). Rhizomes are also important storage organs that enable $P$. australis to send up spring ramets in advance of resident species and to manage nitrogen limitation (Granéli et al. 1992).

Below ground, $P$. australis engineers its habitat to optimize its competitive advantage over native species (Minchinton et al. 2006). For example, a study on $P$. australis roots reported that hypodermal layers around roots and rhizomes protect against toxic organic compounds and anoxia (Armstrong and Armstrong 1988). Aerenchyma channels, which send atmospheric oxygen from emergent plant tissues to plant parts in anoxic soils, also allow $P$. australis to sustain deep rooting depths (Armstrong and Armstrong 1988). For example, studies from a marine coastal marsh gave estimates of $P$. australis roots growing from $<1-4 \mathrm{~m}$ deep (Moore et al. 2012; Packer et al. 2017).

The deep rooting of $P$. australis may be an important strategy for invasion; species with deeper rooting depths are able to access nutrients and minerals lower in the soil profile compared to species with shallow rooting depths (Jobbágy and Jackson 2004). For example, in a New Hampshire study, P. australis had deeper rooting depths in more physically stressful environments that allowed it to access deeper, less saline groundwater and more available nutrients (Moore et al. 2012). Despite the competitive advantage that deep rooting may provide to $P$. australis in salt marshes (Moore et al. 2012), we are not aware of other studies quantifying its rooting depth in freshwater coastal marshes.

Other than the influence of salinity (Moore et al. 2012), variation in $P$. australis rooting depth may be due to differences in water depth, the frequency of water depth fluctuation, and substrate type, which may all influence redox conditions and oxygen availability. For example, in a greenhouse experiment, Hanslin et al. (2017) reported that increased amplitude of water level fluctuations resulted in increased $P$. australis rooting depths but decreased below ground biomass in the top soil regions. This finding has yet to be corroborated by studies of natural systems.

To the best of our knowledge, there are no studies in the Great Lakes region that quantify the vertical distribution and biomass of $P$. australis below ground tissues compared to resident vegetation, particularly not across a gradient in water depth. Differences in rooting depth between invasive $P$. australis and resident plant communities in these freshwater wetlands may help explain the success of $P$. australis invasion. Importantly, such differences may also have implications for the ecological effects of invasion. For example, deeper rooting could expand the penetration of oxygen into saturated wetland soils (Faußer et al. 2016), mobilizing carbon pools and metals that were otherwise inactive (e.g., Jacob and Otte 2003). We sought to determine if freshwater coastal marsh communities dominated by invasive $P$. australis have greater below ground biomass or deeper rooting depths compared with resident uninvaded marsh. We predicted that more below ground biomass would be produced by $P$. australis than resident plant communities because $P$. australis is so productive (Rothman and Bouchard 2007). Also, because $P$. australis has deeper rooting depths than native vegetation in marine coastal marshes (Moore et al. 2012), we predicted that the same trend would be true in freshwater. In addition, because water depth may affect rooting depth (Hanslin et al. 2017), we also tested the prediction that below ground biomass and rooting depth of $P$. australis-dominated communities would be positively correlated with water depth across a naturally occurring gradient and compared this with resident vegetation communities.

\section{Methods}

\section{Site selection}

Our study was situated at Long Point, Canada $\left(42.581^{\circ} \mathrm{N}, 80.381^{\circ} \mathrm{W}\right)$, a sand spit that sustains over $70 \%$ of the remaining intact coastal marsh on the north shore of Lake Erie (Ball et al. 2003). The 40600 ha area is a designated World Biosphere Reserve by the United Nations Educational, Scientific and Cultural Organization (UNESCO), and an internationally important wetland under the Ramsar Convention (Ministry of Natural Resources and Forestry 2017). This ecologically important region is threatened by continuing expansion of high-density $P$. australis (Jung et al. 2017).

Sample sites within Long Point were established across a range of water depths at which $P$. australis invasion is common $(13.7-55.7 \mathrm{~cm})$, with sites dominated by high density $P$. australis monocultures paired by water depth with sites either dominated by cattails (Typha spp.; $>30 \mathrm{~cm}$ water depth) or by meadow taxa, including graminoids, sedges, and forbs (<40 cm water depth). Sites in the 30-40 cm depth range were either meadow marsh or Typha spp. marsh, as the two communities stratify by depth and rarely mix. Sites were dispersed across the Crown 
Marsh and Long Point Provincial Park management units, spaced between 100 and $2000 \mathrm{~m}$ apart. This area is representative of wet meadow and emergent lacustrine marsh in Lake Erie, with substrate ranging from organic in shallower depths to pure sand in deeper locations.

\section{Core collection}

Fieldwork was conducted in May 2017. Using a $2.54 \mathrm{~cm}$ diameter soil gouge auger, soil cores $(0.3-$ $0.75 \mathrm{~m}$ deep) were sampled from sites invaded by $P$. australis and paired uninvaded marsh sites. It was not possible to obtain cores of uniform length due to differences in the thickness of the organic horizon and difficulties penetrating the underlying sand substrate. In total 29 pairs of cores were collected. The cores were then sub-sectioned into $10 \mathrm{~cm}$ long segments and frozen until they could be processed. For comparison, Moore et al. (2012) who also examined belowground biomass trends in marsh invaded by European $P$. australis, collected $100 \mathrm{~cm}$ long cores from 10 tidal marshes along New Hampshire's Atlantic coast using the same diameter gouge auger and sub-sectioned them into $5 \mathrm{~cm}$ long segments.

\section{Core processing}

Core segments were thawed for about $24 \mathrm{~h}$ and then washed over two nested sieves: a coarser (1.7 $\mathrm{mm})$ sieve over a finer $(425 \mu \mathrm{m})$ sieve. All live rhizomes and all root tissues were retrieved and dried at $80^{\circ} \mathrm{C}$ to a constant weight (minimum $48 \mathrm{~h}$ ). Dead roots may have been included in our weights as we did not find it possible to reliably differentiate live and dead roots. The dried below ground tissues were then weighed on a Mettler Toledo analytical balance (MS204S, Columbus, Ohio, USA) with a $0.0001 \mathrm{~g}$ accuracy. For comparison, Moore et al. (2012) picked live roots and rhizomes from trays partially filled with water and then oven dried to a constant weight at $65^{\circ} \mathrm{C}$ for a minimum of $48 \mathrm{~h}$.

\section{Data analysis}

For the purposes of this study, rooting depth was defined as the depth $(\mathrm{cm})$ at which $90 \%$ of the cumulative below ground biomass was accounted for. Below ground biomass was defined as the total root and rhizome mass per unit area $\left(\mathrm{g} / \mathrm{m}^{2}\right)$, recognizing that the core depths varied with the thickness of the organic horizon. To test whether below ground biomass was greater in P. australis invaded sites compared to uninvaded sites, we used a paired-samples, one-tailed $t$-test. To test whether rooting depth was greater in $P$. australis invaded sites than uninvaded sites, we used another paired-samples, one-tailed $t$-test. Lastly, to test whether water depth is a significant predictor of below ground biomass and rooting depth, we used general linear models (GLM) with a least squares estimation framework to model variation in below ground biomass and rooting depth based on water depth, site type (P. australis invaded or uninvaded), and their interaction. Models are thus represented by the general form:

$$
y=\beta_{1} W+\beta_{2} T+\beta_{3} T \times W+\beta_{0}+\varepsilon,
$$

where $W$ is water depth, $T$ is site type, and $\varepsilon$ is error. If the interaction terms were not significant, the model would be re-run to only include the main factors: water depth and site type. In all cases, we used an alpha value of 0.05 and Type III sums of squares. Analyses were completed using IBM SPSS Statistics 20.

\section{Results}

Paired-samples t-tests for below ground biomass and rooting depth

Phragmites australis invaded marsh had greater below ground biomass than uninvaded marsh habitat, when meadow and Typha spp. marsh are considered jointly (paired-samples $t$-test, $t_{28}=3.528, P=0.001$; Figure 1a). Although the difference between Typha spp. dominated cattail marsh and $P$. australis invaded marsh is negligible, it revealed that the difference is primarily between $P$. australis invaded and meadow marsh sites (Figure 1a).

There is no significant difference in rooting depth between $P$. australis invaded marsh and uninvaded marsh (paired-samples $t$-test, $t_{28}=0.992, P=0.330$; Figure 1b). This appears evident in both meadow marsh and cattail marsh components of the uninvaded sites (Figure 1b).

The down-core distribution of below ground biomass suggests that core depths were sufficient to capture the bulk of total below ground tissues (Figure 2). This was true for invaded (Figure 2a) and uninvaded (Figure 2b) sites, across a range of water depth intervals between 13.7 and $55.7 \mathrm{~cm}$. Below ground biomass was detected to a maximum of $80 \mathrm{~cm}$ soil depth yet peaked within the top $30 \mathrm{~cm}$ of the soil profile, regardless of site type (Figure 2).

General linear models for below ground biomass and rooting depth

For below ground biomass, the interaction term was not significant (Table S1a, Figure S1), so we removed it and re-ran the GLM as

$$
\text { below ground biomass }=\beta_{1} W+\beta_{2} T+\beta_{0}+\varepsilon \text {. }
$$

This model provided a reasonable fit (adjusted $r^{2}=$ 0.222; GLM, $F_{2,55}=9.115, P<0.001$; details in Table $\mathrm{S} 1 \mathrm{~b})$. Likewise, for rooting depth, the interaction term was not significant (Table S2a), so we removed it and re-ran the GLM as

$$
\text { rooting depth }=\beta_{1} W+\beta_{2} T+\beta_{0}+\varepsilon .
$$

However, this model proved to be a poor predictor 

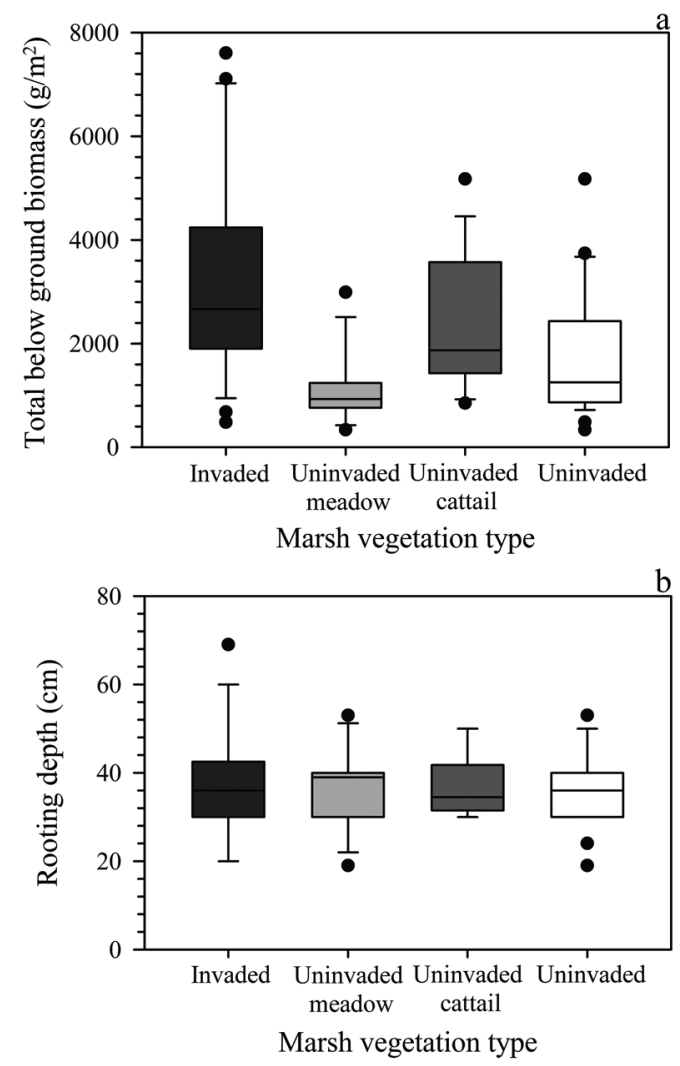

Figure 1. Total below ground biomass and rooting depth in European Reed (Phragmites australis) invaded and uninvaded marsh. Boxplots depicting a. total below ground biomass $\left(\mathrm{g} / \mathrm{m}^{2}\right)$ and $\mathrm{b}$. rooting depth $(\mathrm{cm})$, contrasting $P$. australis invaded marsh (dark grey; $n=29$ ) and uninvaded marsh (white; $n=29$ ) sites. Note that uninvaded marsh is divided into shallower depth meadow marsh (light grey; $n$ $=15$ ) and deeper water cattail (Typha sp.) marsh (grey; $n=$ 14) communities.

of rooting depth (adjusted $r^{2}=0.006$; GLM, $F_{2,55}=$ $1.175, P=0.316$; details in Table S2b).

\section{Discussion}

Our research objectives were to determine if $P$. australis invaded marsh produced more below ground biomass, and deeper rooting depths than uninvaded marsh in a freshwater coastal marsh, as has been observed in marine coastal marshes (e.g., Ravit et al. 2006; Moore et al. 2012). Controlling for water depth, we observed that $P$. australis invaded marsh had more below ground biomass than uninvaded marsh, however, rooting depths did not differ significantly between $P$. australis invaded and uninvaded marsh sites. Like site type, water depth was a significant predictor of below ground biomass $\left(\mathrm{g} / \mathrm{m}^{2}\right)$ but not of rooting depth. Interestingly, although the largest difference in below ground biomass was evident between $P$. australis invaded sites and meadow marsh sites, which were restricted to shallower water depths, we detected no significant interaction between water depth and site type when predicting either below ground biomass or rooting depth.

Greater below ground biomass may provide $P$. australis a competitive advantage allowing it to usurp soil resources (van Wijk et al. 2003) and facilitate dispersion by vegetative reproduction (Saltonstall 2002; Tulbure and Johnston 2010; Albert et al. 2015). The current literature reports below ground biomass values for $P$. australis in the range of $886 \mathrm{~g} / \mathrm{m}^{2}$ (Rothman and Bouchard 2007) to $1368 \mathrm{~g} / \mathrm{m}^{2}$ (Windham 2001); for cattail marsh in the range of $742 \mathrm{~g} / \mathrm{m}^{2}$ (Rothman and Bouchard 2007) to $2461 \mathrm{~g} / \mathrm{m}^{2}$ (Ouellet-Plamondon et al. 2004); and for meadow species, such as Saltmeadow Cordgrass (Sporobolus pumilus (Roth) P.M. Peterson \& Saarela) and Bluejoint Reedgrass (Calamagrostis canadensis (Michaux) Palisot de Beauvois), in the range of $256 \mathrm{~g} / \mathrm{m}^{2}$ (Ouellet-Plamondon et al. 2004) to $757 \mathrm{~g} / \mathrm{m}^{2}$ (Windham 2001). Our measures of below ground biomass show the same pattern in relative magnitude among the three communities but are noticeably higher than other published values: averaging $3137 \mathrm{~g} /$ $\mathrm{m}^{2}$ for P. australis, $2372 \mathrm{~g} / \mathrm{m}^{2}$ for cattail marsh, and $1146 \mathrm{~g} / \mathrm{m}^{2}$ for meadow marsh. Our measurements may be high due to particularly dense growth, favourable edaphic conditions in intact freshwater coastal marsh, or because we were unable to differentiate live tissues from recently dead tissues.

When uninvaded marsh was separated into cattail and meadow marsh communities, we noted higher average below ground biomass in uninvaded cattail marsh, clearly overlapping with the below ground biomass typical of $P$. australis. This indicates that the effects of invasion on below ground biomass is likely more evident where $P$. australis replaces meadow marsh than where it invades cattail marsh. Yet, despite this difference in mean below ground biomass between cattail and meadow marsh, we fit a single slope relating the below ground biomass of uninvaded sites to water depth collectively. Future research should explicitly test for the role of resident vegetation community type on limiting the magnitude of $P$. australis invasion effects on invaded ecosystems.

Importantly, though invasion by $P$. australis in freshwater coastal marsh may increase overall below ground biomass, the concern that $P$. australis below ground tissues might penetrate more deeply than resident species and thus alter nutrient and metal fluxes in freshwater marshes is unfounded. Contrary to previous studies (e.g., Ravit et al. 2006; Moore et al. 2012), we observed no difference in rooting depth 

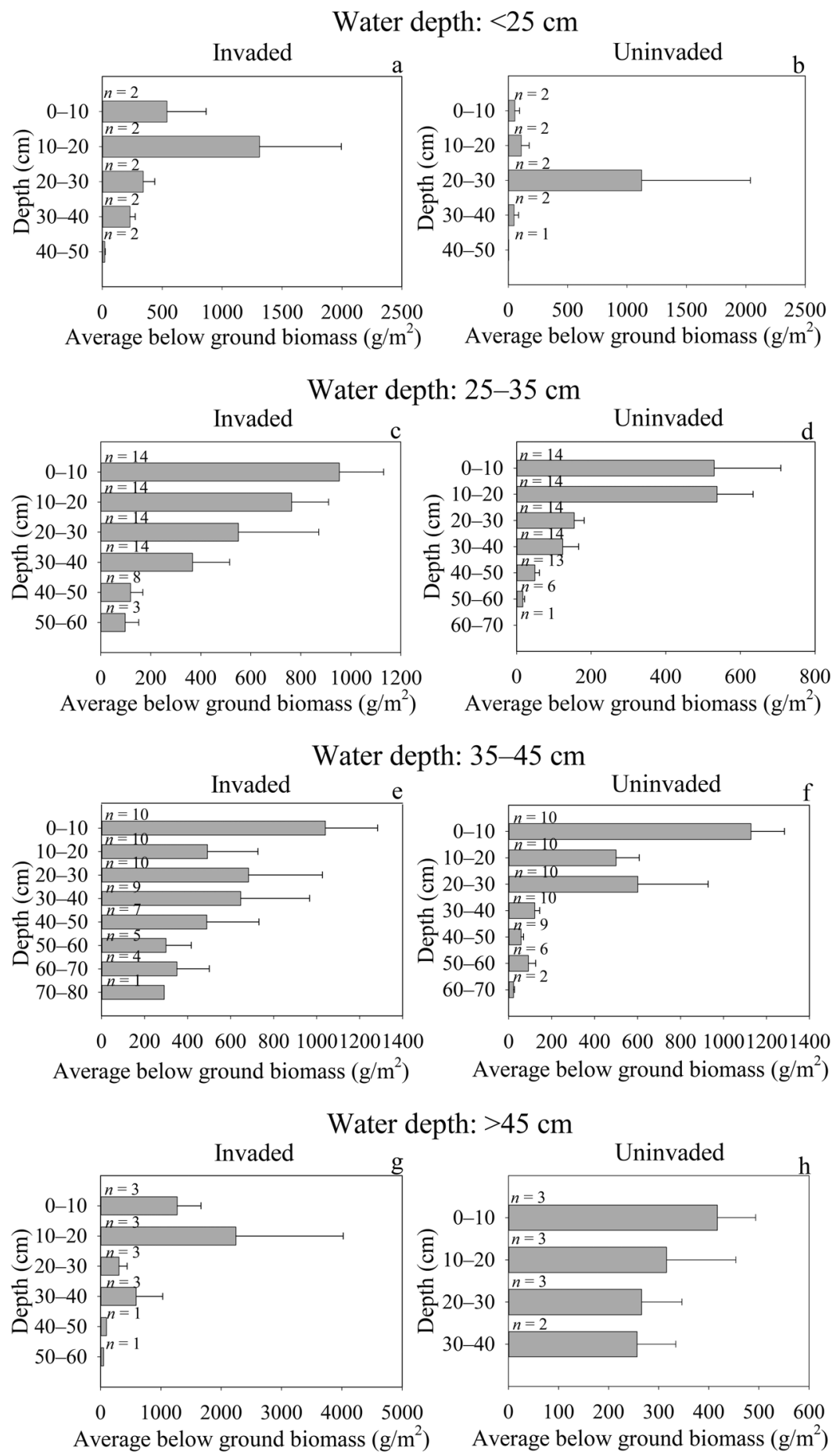

Figure 2. Down-core distribution of below ground biomass at different water depths. Down-core distribution of below ground biomass, contrasting European Reed (Phragmites australis) invaded sites (a, c, e, g) and uninvaded sites (b, d, f, h) at different water depth intervals: $<25 \mathrm{~cm}(\mathrm{a}, \mathrm{b})$, between $25-35 \mathrm{~cm}(\mathrm{c}, \mathrm{d})$, between $35-45 \mathrm{~cm}(\mathrm{e}, \mathrm{f})$, and $>45 \mathrm{~cm}(\mathrm{~g}, \mathrm{~h})$. The $n$ above each bar indicates the number of cores in which living below ground tissues were detected at the indicated water and soil depth, in the indicated site type. Error bars are SE. 
among the invaded and uninvaded sites. Moore et al. (2012) surmised that in marine coastal marsh, P. australis may produce deeper roots to access freshwater pockets. If this were so, it might explain why $P$. australis was not rooting more deeply than resident species in our freshwater coastal marsh. Alternatively, these published studies may differ from ours in the frequency and amplitude of water depth fluctuations that can also influence rooting depth (Hanslin et al. 2017). Another important factor is likely the wetland soil type and stratigraphy. Moore et al. (2012) reported that sandy mineral soils may inhibit deep penetration of roots. Long Point has a sand mineral soil beneath an organic horizon of variable thickness; the sand soil may have limited rooting depth for all species in our study.

Because $P$. australis produces significantly more below ground biomass in the same depth of rhizosphere as resident vegetation communities, we expect that root processes such as enhanced gas diffusion in the rhizosphere, oxidation of waterlogged anoxic soils (Armstrong and Armstrong 1988; Bart and Hartmann 2000), and the release of allelochemicals (Rudrappa et al. 2007) provide $P$. australis a competitive advantage and contribute to its invasion success. Yet clearly, given the equivalent rooting depths of $P$. australis invaded and uninvaded marsh, these communities experience a common rooting depth limit. This conclusion is further supported by our observation that meadow marsh, despite producing less below ground biomass than cattail marsh, nonetheless roots at an equivalent depth

\section{Conclusion}

Below ground biomass in $P$. australis invaded marsh significantly exceeded that in resident communities of meadow marsh and cattail marsh, after accounting for water depth, but rooting depths were equivalent. Consequently, root densities must be greater in $P$. australis invaded marsh, potentially contributing to its invasion success in Long Point. Because $P$. australis did not root more deeply than resident vegetation in our freshwater coastal marsh study system, concerns around invasion mobilizing deep pools of otherwise inactive carbon or metals may be generally unwarranted. The novel quantitative data presented in this study increases our understanding of $P$. australis invasion in freshwater lacustrine coastal marsh habitat and establishes the hypothesis of common limits to rooting depth in invaded and uninvaded sites that should be tested in other study systems.

\section{Author Contributions}

Conception \& Design: R.C.R., S.J.Y., and C.L.; Field Work: S.J.Y.; Lab Work: C.L. and S.J.Y.; Data
Analysis \& Interpretation: R.C.R., S.J.Y., and C.L.; Writing - First Draft: C.L.; Writing - Review \& Editing: R.C.R., S.J.Y., and C.L.; Funding Acquisition: R.C.R.

\section{Acknowledgements}

This work was supported by NSERC Discovery Grant \#RGPIN 2014-03846 to R.C.R., Mitacs Accelerate, the Nature Conservancy of Canada, and the Ontario Graduate Scholarship program. We would like to thank Ministry of Natural Resources and Forestry Aylmer District and Ontario Parks for providing site access. We are grateful to Courtney Robichaud, Jessie Pearson, Graham Howell, Taylor Blackwell, Madison Brook, Bailey Dhanani, Megan Jordan, Lauren Koiter, Cindy Luu, Christine Nielsen, and Alina Steele for their participation in conducting the field and lab work necessary for this study. We thank Dr. Roland Hall for his insight and feedback on an early draft of this paper and Dr. Paul Catling for useful feedback during the review process.

\section{Literature Cited}

Able, K.W., S.M. Hagan, and S.A. Brown. 2003. Mechanisms of marsh habitat alteration due to Phragmites: response of young-of-the-year mummichog (Fundulus heteroclitus) to treatment for Phragmites removal. Estuaries 26: 484-494. https://doi.org/10.1007/bf02823725

Albert, A., J. Brisson, F. Belzile, J. Turgeon, and C. Lavoie. 2015. Strategies for a successful plant invasion: the reproduction of Phragmites australis in north-eastern North America. Journal of Ecology 103: 1529-1537. https:// doi.org/10.1111/1365-2745.12473

Armstrong, J., and W. Armstrong. 1988. Phragmites australis - a preliminary study of soil-oxidizing sites and internal gas transport pathways. New Phytologist 108: 373-382. https://doi.org/10.1111/j.1469-8137.1988.tb04177.x

Ball, H., J. Jalava, T. King, L. Maynard, B. Potter, and T. Pulfer. 2003. The Ontario Great Lakes coastal wetland atlas: a summary of information (1983-1997). Environment Canada, Peterborough, Ontario, Canada.

Bart, D., and J.M. Hartman. 2000. Environmental determinants of Phragmites australis expansion in a New Jersey salt marsh: an experimental approach. Oikos 89: 59-69. https://doi.org/10.1034/j.1600-0706.2000.890 107.x

Bolton, R.M., and R.J. Brooks. 2010. Impact of the seasonal invasion of Phragmites australis (Common Reed) on turtle reproductive success. Chelonian Conservation and Biology 9: 238-243. https://doi.org/10.2744/CCB0793.1

Bourgeau-Chavez, L.L., K.P. Kowalski, M.L. Carlson Mazur, K.A. Scarbrough, R.B. Powell, C.N. Brooks, B. Huberty, L.K. Jenkins, E.C. Banda, D.M. Galbraith, Z.M. Laubach, and K. Riordan. 2013. Mapping invasive Phragmites australis in the coastal Great Lakes with ALOS PALSAR satellite imagery for decision support. Journal of Great Lakes Research 39: 6577. https://doi.org/10.1016/j.jglr.2012.11.001 
Carson, B.D., S.C. Lishawa, N.C. Tuchman, A.M. Monks, B.A. Lawrence, and D.A. Albert. 2018. Harvesting invasive plants to reduce nutrient loads and produce bioenergy: an assessment of Great Lakes coastal wetlands. Ecosphere 9: 1-16. https://doi.org/10.1002/ecs2.2320

Catling, P.M., and G. Mitrow. 2005. A prioritized list of the invasive alien plants of natural habitats in Canada. Canadian Botanical Association Bulletin 38: 55-57.

Catling, P.M., and G. Mitrow. 2011. Major invasive alien plants of natural habitats in Canada. 1. European Common Reed, Phragmites australis (Cav.) Trin. ex Steud. subsp. australis. Canadian Botanical Association Bulletin 44: 52-61.

Cook, C. 2016. Impacts of invasive Phragmites australis on diamondback terrapin nesting. M.Sc. thesis, College of William and Mary, Williamsburg, Virginia, USA.

Duke, S.T., S.N. Francoeur, and K.E. Judd. 2015. Effects of Phragmites australis invasion on carbon dynamics in a freshwater marsh. Wetlands 35: 311-321. https://doi.org/10.1007/s13157-014-0619-x

Faußer, A.C., J. Dušek, H. Čížková, and M. Kazda. 2016. Diurnal dynamics of oxygen and carbon dioxide concentrations in shoots and rhizomes of a perennial in a constructed wetland indicate down-regulation of below ground oxygen consumption. AoB PLANTS 8: 1-15. https://doi.org/10.1093/aobpla/plw025

Granéli, W., S.E.B. Weisner, and M.D. Sytsma. 1992. Rhizome dynamics and resource storage in Phragmites australis. Wetlands Ecology and Management 1: 239257. https://doi.org/10.1007/BF00244929

Greenberg, D.A., and D.M. Green. 2013. Effects of an invasive plant on population dynamics in toads. Conservation Biology 27: 1049-1057. https://doi.org/10.1111/ cobi.12078

Hanslin, H.M., T. Mæhlum, and A. Sæbø. 2017. The response of Phragmites to fluctuating subsurface water levels in constructed stormwater management systems. Ecological Engineering 106: 385-391. https://doi.org/ 10.1016/j.ecoleng.2017.06.019

Hirtreiter, J.N., and D.L. Potts. 2012. Canopy structure, photosynthetic capacity and nitrogen distribution in adjacent mixed and monospecific stands of Phragmites australis and Typha latifolia. Plant Ecology 213: 821829. https://doi.org/10.1007/s11258-012-0044-2

Jacob, D.L., and M.L. Otte. 2003. Conflicting processes in the wetland plant rhizosphere: metal retention or mobilization? Water, Air and Soil Pollution: Focus 3: 91104. https://doi.org/10.1023/a:1022138919019

Jobbágy, E.G., and R.B. Jackson. 2004. The uplift of soil nutrients by plants: biogeochemical consequences across scales. Ecology 85: 2380-2389. https://doi.org/ 10.1890/03-0245

Jung, J.A., D. Rokitnicki-Wojcik, and J.D. Midwood. 2017. Characterizing past and modelling future spread of Phragmites australis ssp. australis at Long Point Peninsula, Ontario, Canada. Wetlands 37: 961-973. https://www.doi.org/10.1007/s13157-017-0931-3

Keller, B.E.M. 2000. Plant diversity in Lythrum, Phragmites, and Typha marshes, Massachusetts, U.S.A. Wetlands Ecology and Management 8: 391-401. https://doi. org/10.1023/a:1026505817409
Mal, T.K., and L. Narine. 2004. The biology of Canadian weeds. 129. Phragmites australis (Cav.) Trin. ex Steud. Canadian Journal of Plant Science 84: 365-396. https:// doi.org/10.4141/P01-172

Minchinton, T.E., J.C. Simpson, and M.D. Bertness. 2006. Mechanisms of exclusion of native coastal marsh plants by an invasive grass. Journal of Ecology 94: 342 354. https://doi.org/10.1111/j.1365-2745.2006.01099.x

Ministry of Natural Resources and Forestry. 2017. Invasive Phragmites control at Long Point Region and Rondeau Provincial Park implementation plan. Ministry of Natural Resources and Forestry, Aylmer District, Ontario Parks, Southwest Zone.

Moore, G.E., D.M. Burdick, C.R. Peter, and D.R. Keirstead. 2012. Belowground biomass of Phragmites australis in coastal marshes. Northeastern Naturalist 19: 611-626. https://doi.org/10.1656/045.019.0406

Ouellet-Plamondon, C.M., J. Brisson, and Y. Comeau. 2004. Effect of macrophyte species on subsurface flow wetland performance in cold climate. Pages 8-15 in Proceedings of the 2004 Self-Sustaining Solutions for Streams, Wetlands, and Watersheds Conference, St. Paul, Minnesota, September 2004. American Society of Agricultural Engineers, St. Joseph, Minnesota, USA. https://doi.org/10.13031/2013.17368

Packer, J.G., L.A. Meyerson, H. Skálová, P. Pyšek, and C. Kueffer. 2017. Biological Flora of the British Isles: Phragmites australis. Journal of Ecology 105: 11231162. https://doi.org/10.1111/1365-2745.12797

Ravit, B., J.G. Ehenfeld, and M.M. Häggblom. 2006. Effects of vegetation on root-associated microbial communities: a comparison of disturbed versus undisturbed estuarine sediments. Soil Biology and Biochemistry 38: 2359-2371. https://doi.org/10.1016/j.soilbio.2006.02.012

Robichaud, C.D., and R.C. Rooney. 2017. Long-term effects of a Phragmites australis invasion on birds in a Lake Erie coastal marsh. Journal of Great Lakes Research 43: 141-149. https://doi.org/10.1016/j.jglr.2017.03. 018

Rothman, E., and V. Bouchard. 2007. Regulation of carbon processes by macrophyte species in a Great Lakes coastal wetland. Wetlands 27: 1134-1143. https://doi. org/10.1672/0277-5212(2007)27[1134:rocpbm]2.0.co;2

Rudrappa, T., J. Bonsall, J.L. Gallagher, D.M. Seliskar, and H.P. Bais. 2007. Root-secreted allelochemicals in the noxious weed Phragmites australis deploys a reactive oxygen species response and microtubule assembly disruption to execute rhizotoxicity. Journal of Chemical Ecology 33: 1898-1918. https://doi.org/10.1007/s10886007-9353-7

Saltonstall, K. 2002. Cryptic invasion by a non-native genotype of the common reed, Phragmites australis, into North America. Proceedings of the National Academy of Sciences 99: 2445-2449. https://doi.org/10.1073/pnas. 032477999

Tulbure, M.G., and C.A. Johnston. 2010. Environmental conditions promoting non-native Phragmites australis expansion in Great Lakes coastal wetlands. Wetlands 30: 577-587. https://doi.org/10.1007/s13157-010-0054-6 van Wijk, M.T., M. Williams, L. Gough, S.E. Hobbie, 
and G.R. Shaver. 2003. Luxury consumption of soil nutrients: a possible competitive strategy in aboveground and below-ground biomass allocation and root morphology for slow-growing arctic vegetation? Journal of Ecology 91: 664-676. https://doi.org/10.1046/ j.1365-2745.2003.00788.x

Wilcox, K.L., S.A. Petrie, L.A. Maynard, and S.W. Meyer. 2003. Historical distribution and abundance of Phragmites australis at Long Point, Lake Erie, Ontario. Journal of Great Lakes Research 29: 664-680. https:// doi.org/10.1016/S0380-1330(03)70469-9

Windham, L. 2001. Comparison of biomass production and decomposition between Phragmites australis (common reed) and Spartina patens (salt hay grass) in brackish tidal marshes of New Jersey, USA. Wetlands 21: 179-188. https://doi.org/10.1672/0277-5212(2001)021[0179:cob pad]2.0.co;2

Windham, L., and J.G. Ehrenfeld. 2003. Net impact of a plant invasion on nitrogen-cycling processes within a brackish tidal marsh. Ecological Application 13: 883896. https://doi.org/10.1890/02-5005

Received 16 May 2019

Accepted 14 February 2020

\section{Supplementary Material:}

Figure S1. Total below ground biomass with water depth for European Reed (Phragmites australis) invaded sites (solid line and black triangles; $n=29$ ) and uninvaded sites (dashed line and white circles; $n=29$ ).

TABLE S1. Results table for GLM predicting total below ground biomass with and without interaction term.

TABLE S2. Results table for GLM predicting rooting depth with and without interaction term. 